\title{
KANDUNGAN MERKURI (Hg) DAGING IKAN NILA (Oreochromis niloticus) YANG DIBUDIDAYAKAN DI KOTA PALANGKA RAYA
}

\author{
MERCURY (Hg) CONTENT OF MEAT TILAPIA FISH \\ (Oreochromis niloticus) WERE CULTIVATED \\ IN PALANGKA RAYA CITY
}

Ciptadi*, Akhmad Damsyik, Heriani

Program Studi Pendidikan Kimia

Jurusan Pendidikan MIPA Fakultas Keguruan dan Ilmu Pendidikan

Universitas Palangka Raya

* Email: ciptadi_solo@yahoo.com

\begin{abstract}
ABSTRAK
Ikan nila banyak dikonsumsi masyarakat Palangka Raya sedangkan ikan ini sebagian besar dipelihara di lingkungan yang terpapar merkuri. Untuk mengetahui apakah ikan nila tersebut telah terkontaminasi oleh merkuri dalam pemeliharaannya, pada penelitian ini telah dilakukan penentuan tentang kandungan merkuri dalam daging ikan nila yang dibudidayakan di Sungai Kahayan, Palangka Raya Kalimantan Tengah. Ikan yang dianalisis dibedakan berdasarkan umur dan tempat budidaya ikan nila yaitu keramba di Sungai Kahayan dan kolam yang terisolasi dari aliran Sungai Kahayan. Data konsentrasi merkuri pada daging ikan nila yang berumur 5-7 bulan yang dipelihara di dalam keramba digunakan untuk mengidentifikasi kandungan merkuri pada ikan nila yang dikeramba di Sungai Kahayan. Data konsentrasi merkuri pada daging ikan nila yang dipelihara di dalam kolam bertujuan untuk membandingkan kandungan merkuri antara ikan nila yang dipelihara di dalam kolam dengan ikan nila yang dipelihara di dalam keramba yang memiliki umur yang sama. Kandungan merkuri dalam sampel diukur menggunakan Mercury Analyzer. Data konsentrasi merkuri pada daging ikan nila dianalisis dengan menggunakan analisis varian (anova : single factor) dengan taraf nyata $(\alpha)$ sebesar $5 \%$. Hasil penelitian menunjukkan bahwa daging ikan nila yang diperoleh dari keramba di Sungai Kahayan umur 5-7 bulan mengandung merkuri sebesar 0,0145 \pm 0,0005 ppm sampai 0,017 $\pm 0,001 \mathrm{ppm}$ lebih rendah dari batas maksimum cemaran merkuri dalam ikan dan hasil olahannya menurut SNI 7387 Tahun 2009 yaitu adalah 0,5 ppm. Dari hasil analisis varian dapat diketahui bahwa terdapat perbedaan kandungan merkuri pada daging ikan nila berdasarkan umur dan tempat budidaya. Kandungan merkuri pada daging ikan nila umur 5 sampai 7 bulan mengalami peningkatan dan kandungan merkuri pada ikan nila yang dibudidayakan di kolam yang terisolasi lebih rendah daripada kandungan merkuri pada daging ikan nila yang dibudidayakan di keramba pada umur ikan yang sama yaitu sebesar 0,0115 $\pm 0,0005 \mathrm{ppm}$.
\end{abstract}

Kata kunci : daging ikan nila, keramba, merkuri

\begin{abstract}
Tilapia fish as Palangkarayan food are mostly cultivated in the river which exposed by mercury. To get information whether the fish have been contaminated by mercury, the
\end{abstract}


mercury determination of tilapia fish meat cultivated in Kahayan river was carried out. The fish were analyzed based on age and the cultivation environment that are fishes cages in Kahayan river and isolated pond from streams of Kahayan river) are also studied. The concentration of mercury in the flesh of tilapia with 5-7 months, kept in cages used to identify the content of mercury in fish tilapia cages in Kahayan river. The concentration of mercury in the flesh of tilapia reared in ponds aims to compare the mercury content in the tilapia in ponds the same age were used as comparison. The level of mercury in the samples was measured using a Mercury Analyzer. Data concentration of mercury in the flesh of tilapia were analyzed using analysis of variance (ANOVA: single factor) with a significance level $(\alpha)$ of $5 \%$. The results showed that tilapia fish meat from the cages in the Kahayan river with age of 5-7 months contain mercury as much as $0.0145 \pm 0.0005 \mathrm{ppm}$ to $0.017 \pm 0.001 \mathrm{ppm}$, which were lower than the maximum limit of mercury contamination in fish and processed products regulated by ISO 7387 in 2009 of $0.5 \mathrm{ppm}$. The the analysis of variance showed that the mercury content in tilapia fish meat was different by age and place of cultivation. The content of mercury in the tilapia fish meat increase with the increase of their age. The mercury content in tilapia fish cultivated in the isolated pond lower than that of in the tilapia fish meat cultivated in cages of $0.0115 \pm$ $0.0005 \mathrm{ppm}$.

Keywords : cages, meat of tilapia fish, mercury

\section{PENDAHULUAN}

Sungai Kahayan merupakan sentra budidaya keramba Kota Palangka Raya. Jenis ikan yang dibudidayakan para pembudidaya keramba di sungai ini adalah ikan mas (Cyprinus carpio), nila (Oreochromis niloticus) dan patin (Pangasius pangasius ham). Selain ketiga jenis ikan tersebut, ikan gurami (Osphronemus goramy), bawal air tawar (Colossoma macropomum cuvier) dan toman (Channa micropeltes) juga dibudidayakan oleh penduduk yang berada di bantaran Sungai Kahayan. Berdasarkan hasil penelitian yang telah dilakukan di Laboratorium Balai Riset Teknik Industri (Baristan) Banjar Baru Kalimantan Selatan pada sampel air di daerah aliran sungai (DAS) Kahayan di Kecamatan Banama Tingang Kalimantan Tengah pada akhir tahun 2012 menunjukkan bahwa air Sungai Kahayan telah tercemar oleh merkuri sebesar 0,004 ppm (Vensensius, 2013). Hasil analisis yang dilakukan di Laboratorium Pendidikan Kimia, FKIP, Universitas Palangkaraya terhadap sampel air Sungai Kahayan yang diambil di dekat Pelabuhan Rambang Kota Palangka Raya pada Bulan Oktober 2013 menunjukan bahwa kandungan merkuri pada air Sungai Kahayan sebesar 0,002 ppm yang telah melebihi ambang batas kadar merkuri yang diperbolehkan adalah 0,001 ppm.

Informasi dari Dinas Kelautan dan Perikanan Provinsi Kalimantan Tengah pada tahun 2013 menunjukkan bahwa konsumsi ikan nila menempati urutan kedua setelah ikan patin. Ikan nila merupakan ikan omnivora sehingga ikan ini berpeluang cukup besar dalam mengakumulasi merkuri di perairan (habitatnya). Apabila ikan tersebut dikonsumsi oleh masyarakat secara terusmenerus maka besar kemungkinan masyarakat yang mengkonsumsi ikan nila tersebut juga akan menumpuk merkuri dalam jumlah yang signifikan karena terjadi akumulasi merkuri di dalam tubuh mereka. Merkuri di dalam tubuh manusia dapat mengganggu sistem syaraf, ginjal dan organ pernafasan (Jewett dan Duffy, 2007).

Karena ikan nila banyak dikonsumsi oleh masyarakat Palangka Raya padahal ikan ini sebagian besar dipelihara di lingkungan yang terpapar merkuri, maka untuk memperoleh gambaran apakah ikan nila tersebut ikut terkontaminasi oleh 
merkuri dalam pemeli-haraannya maka dalam penelitian ini dikaji kandungan merkuri daging ikan nila yang dibudidayakan di Kota Palangka Raya.

\section{METODE PENELITIAN}

\section{Alat dan Bahan Penelitian}

Alat yang digunakan di laboratorium terdiri atas Mercury Analyzer NIC MA3000, neraca, pinset (penjepit), labu takar, pipet tetes, mikropipet, tips, botol semprot, lumpang dan alu. Mercury Analyzer NIC MA3000 merupakan alat yang dapat mengukur merkuri total pada sampel padat, cair dan gas dengan menggunakan prinsip thermal decomposition, gold-amalgamation dan cold-vapor atomic absorption spectroscopy tanpa persiapan sampel.

Bahan yang digunakan di laboratorium terdiri atas sampel utama, sampel pendukung dan bahan-bahan yang digunakan untuk analisis di laboratorium seperti larutan merkuri standar, additive $B$ (khusus untuk Mercury Analyzer), sistein, etanol, aquades, dan tissue. Sampel utama terdiri dari daging ikan nila yang dibudidayakan di Sungai Kahayan dari umur 5-7 bulan dan daging ikan nila berumur 5 bulan yang dibudidayakan di kolam Jalan G. Obos XXV Kota Palangka Raya. Sampel pendukung terdiri dari air dan tanaman yang tumbuh di dekat keramba ikan nila di Sungai Kahayan, air dan tanaman yang tumbuh di kolam ikan nila.

\section{Prosedur Penelitian}

Pada penelitian ini digunakan 3 keramba di Sungai Kahayan Kota Palangka Raya. Keramba 1 terletak di Jalan Wisata 1 bagian hulu $\left(02^{\circ} 12^{\prime} 08,2^{\prime \prime} \mathrm{LS}\right.$ dan $\left.113^{\circ} 56^{\prime} 25,1^{\prime \prime} \mathrm{BT}\right)$, keramba 2 terletak di Jalan Sanggarahan $\left(02^{\circ} 12^{\prime} 09,1^{\prime \prime} \mathrm{LS}\right.$ dan $113^{\circ} 56^{\prime} 33,3^{\prime \prime} \mathrm{BT}$ ) dan keramba 3 terletak di Jalan Wisata 1 bagian hilir $\left(02^{\circ} 12^{\prime} 10,2^{\prime \prime} \mathrm{LS}\right.$ dan $113^{\circ} 56^{\prime} 07,2^{\prime \prime}$ BT). Ikan nila yang dijadikan sampel penelitian dari masing- masing keramba diambil dari umur 5-7 bulan, dimana ikan yang mempunyai umur yang sama diambil sebanyak 3 ekor. Sebagai kontrol dipilih ikan nila berumur 5 bulan hasil budidaya kolam di Jalan G. Obos XXV Kota Palangka Raya sebanyak 3 ekor dengan kriteria kolam ikan nila yang dipilih yaitu kolam yang terisolasi dari aliran Sungai Kahayan dan berjarak cukup jauh dari jalan raya.

Sebelum dilakukan analisis, ikan nila dibersihkan terlebih dahulu kemudian diambil bagian dagingnya. Bagian daging yang diambil dari badan ikan pada semua sampel harus sama supaya data yang diperoleh merupakan kandungan merkuri dari bagian yang sama pada tubuh ikan. Setelah itu, daging ikan dihaluskan dan dicampur sampai merata. Daging ikan kemudian ditimbang untuk mengukur massanya, lalu dimasukan ke tempat sampel dan disusun pada tray. Tray tersebut dimasukan ke dalam Mercury Analyzer dan dianalisis kandungan merkurinya dengan terlebih dahulu melakukan pengaturan pada perangkat lunak di alat tersebut, misalnya membuat kurva kalibrasi standar, memasukan data berupa jenis dan massa sampel yang dianalisis serta satuan konsentrasi yang diinginkan ( $p p t, p p b$ dan ppm). Setelah tahapan analisis merkuri pada alat telah selesai maka kandungan merkuri pada daging ikan nila dapat diketahui.

Data konsentrasi merkuri pada daging ikan nila yang berumur 5-7 bulan yang dipelihara di dalam keramba Sungai Kahayan digunakan untuk mengidentifikasi kandungan merkuri pada ikan nila yang dikeramba di Sungai Kahayan dan mendeskripsikan kandungan merkuri pada daging ikan tersebut berdasarkan umur ikan dengan menggunakan analisis varian (anova : single factor).

Data konsentrasi merkuri pada daging ikan nila yang dipelihara di dalam kolam bertujuan untuk membandingkan kandungan merkuri antara ikan nila yang 
dipelihara di dalam kolam dengan ikan nila yang dipelihara di dalam keramba yang memiliki umur yang sama dan data tersebut akan dianalisis dengan menggunakan analisis varian (anova : single factor).

\section{HASIL DAN PEMBAHASAN}

Kandungan Merkuri pada Daging Ikan Nila yang Diperoleh dari Keramba di Sungai Kahayan

Kandungan merkuri pada daging ikan nila tersebut dapat dilihat pada Tabel 1. Berdasarkan data pada Tabel 1 dapat diketahui bahwa ikan nila berumur 5-7 bulan yang dibudidayakan di dalam keramba di Sungai Kahayan telah terkontaminasi merkuri. Kandungan merkuri paling rendah ditemukan pada daging ikan nila berumur 5 bulan yaitu sebesar 0,0145 $\pm 0,0005$ ppm sedangkan kandungan merkuri paling tinggi adalah daging ikan nila berumur 7 bulan sebesar $0,017 \pm 0,001 \mathrm{ppm}$. Jumlah kandungan merkuri pada ikan nila yang dibudidayakan di Sungai Kahayan masih dalam jumlah yang aman untuk dikonsumsi karena berdasarkan Standar Nasional Indonesia (SNI) 7387 Tahun 2009 tentang batas maksimum cemaran merkuri dalam ikan dan hasil olahannya adalah 0,5 ppm. Namun jika ikan nila yang mengandung merkuri tersebut dikonsumsi terus-menerus oleh manusia maka besar kemungkinan manusia tersebut akan terkontaminasi dan mengakumulasi merkuri dalam jumlah yang signifikan sehingga tetap dapat membahayakan kesehatan.

Adanya merkuri dalam ikan nila yang dibudidayakan di dalam keramba di Sungai Kahayan diduga berasal dari air sungai yang telah tercemar oleh merkuri yang mengkontaminasi tubuh ikan nila. Kontaminasi tersebut dapat melalui kulit, saluran pernafasan dan saluran pencernaan. Sumber pencemaran merkuri pada sungai Sungai Kahayan tempat ikan nila dibudidayakan kemungkinan berasal dari air sungai Kahayan yang telah tercemar merkuri, yaitu $0.002 \mathrm{ppm}$.

Tabel 1. Kandungan merkuri daging ikan nila yang diperoleh dari keramba di Sungai Kahayan

\begin{tabular}{ccccc}
\hline Umur Ikan & $\begin{array}{c}\text { Keramba 1 } \\
(\mathbf{p p m})\end{array}$ & $\begin{array}{c}\text { Keramba 2 } \\
(\mathbf{p p m})\end{array}$ & $\begin{array}{c}\text { Keramba 3 } \\
(\mathbf{p p m})\end{array}$ & $\begin{array}{c}\text { Rerata } \\
(\mathbf{p p m})\end{array}$ \\
\hline 5 & 0,014 & 0,014 & 0,015 & $0,0145 \pm 0,0005$ \\
6 & 0,017 & 0,015 & 0,015 & $0,016 \pm 0,001$ \\
7 & 0,018 & 0,018 & 0,016 & $0,017 \pm 0,001$
\end{tabular}

Sumber : Data primer diolah

Kandungan Merkuri pada Daging Ikan Nila yang Diperoleh dari Keramba Di Sungai Kahayan Berdasarkan Umur Ikan

Untuk mengetahui apakah terdapat perbedaan kandungan merkuri pada daging ikan nila pada keramba 1 berdasarkan umur ikan maka digunakan analisis varian (anova : single factor) dengan taraf nyata (a) sebesar 5\%. Berdasarkan analisis varian dapat diketahui bahwa $F_{0}=3,619$ dan $F_{\alpha}=3,403$ sehingga dapat disimpulkan bahwa nilai $\mathrm{F}_{0}$ lebih besar dari nilai $\mathrm{F}_{\alpha}\left(\mathrm{F}_{0}\right.$ $>\mathrm{F}_{\alpha}$ ). Hal ini dapat menunjukkan bahwa $\mathrm{H}_{0}\left(\mu_{1}=\mu_{2}=\mu_{3}\right)$ ditolak dan $\mathrm{H}_{1}\left(\mu_{1} \neq \mu_{2} \neq\right.$ $\left.\mu_{3}\right)$ diterima. Artinya, kandungan merkuri pada daging ikan nila berumur 5 bulan tidak sama dengan kandungan merkuri pada daging ikan nila berumur 6 bulan dan tidak sama dengan kandungan merkuri pada daging ikan nila berumur 7 bulan. Dengan kata lain, terdapat perbedaan kandungan merkuri pada daging ikan nila keramba 1 antara umur 5, 6 dan 7 bulan. 
Kandungan merkuri rerata pada daging ikan nila dari umur 5-6 bulan mengalami peningkatan. Untuk daging ikan nila umur 5 bulan adalah 0,014 ppm, 6 bulan adalah 0,017 ppm dan 7 bulan adalah 0,018 ppm. Terjadinya akumulasi merkuri dalam tubuh ikan kemungkinan disebabkan karena ikan dapat menyerap merkuri dengan efisien, tetapi ketika mengeluarkannya dari tubuh sangatlah lambat sehingga semakin panjang atau lama ikan nila terpapar merkuri maka kandungan merkuri dalam tubuh ikan tersebut akan semakin banyak. Hal tersebut sama seperti hasil penelitian yang dilakukan oleh Jewett dan Duffy mengenai konsentrasi merkuri total pada ikan segar di Alaska, dimana konsentrasi merkuri pada jenis ikan dan lokasi pengambilan sampel yang sama pada tahun 1997 ke tahun 2000 mengalami peningkatan yaitu dari 1,07 ppm menjadi 1,51 ppm (Jewett dan Duffy, 2007).

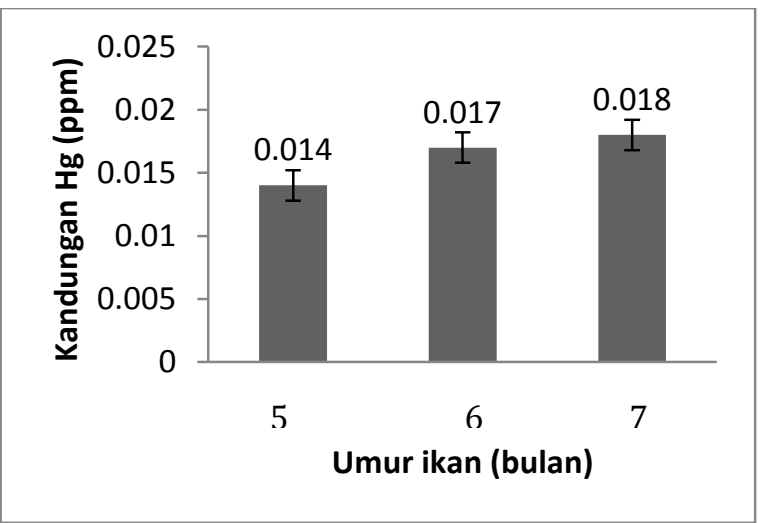

Gambar 1. Diagram kandungan merkuri rerata pada daging ikan nila umur 5-7 bulan pada keramba 1

Untuk mengetahui apakah terdapat perbedaan kandungan merkuri pada daging ikan nila pada keramba 2 berdasarkan umur ikan maka digunakan analisis varian (anova : single factor) dengan taraf nyata ( $\alpha$ ) sebesar 5\%. Berdasarkan analisis varian dapat diketahui bahwa $\mathrm{F}_{0}=10,765$ dan $F_{\alpha}=3,403$ sehingga dapat disimpulkan bahwa nilai $F_{0}$ lebih besar dari nilai $F_{\alpha}\left(F_{0}\right.$ $>\mathrm{F}_{\alpha}$ ). Hal ini dapat menunjukkan bahwa $\mathrm{H}_{0}\left(\mu_{1}=\mu_{2}=\mu_{3}\right)$ ditolak dan $\mathrm{H}_{1}\left(\mu_{1} \neq \mu_{2} \neq\right.$ $\left.\mu_{3}\right)$ diterima. Artinya, kandungan merkuri pada daging ikan nila berumur 5 bulan tidak sama dengan kandungan merkuri pada daging ikan nila berumur 6 bulan dan tidak sama dengan kandungan merkuri pada daging ikan nila berumur 7 bulan.
Dengan kata lain, terdapat perbedaan kandungan merkuri pada daging ikan nila keramba 2 antara umur 5, 6 dan 7 bulan.

Kandungan merkuri rerata pada daging ikan nila dari umur 5-6 bulan mengalami peningkatan. Untuk daging ikan nila umur 5 bulan adalah 0,014 ppm, 6 bulan adalah 0,015 ppm dan 7 bulan adalah 0,018 ppm. Hal ini disebabkan karena terjadinya akumulasi merkuri dalam tubuh ikan, dimana ikan dapat menyerap merkuri dengan efisien, tetapi ketika mengeluarkannya dari tubuh sangatlah lambat sehingga semakin panjang atau lama ikan nila terpapar merkuri maka kandungan merkuri dalam tubuh ikan tersebut akan semakin banyak. 


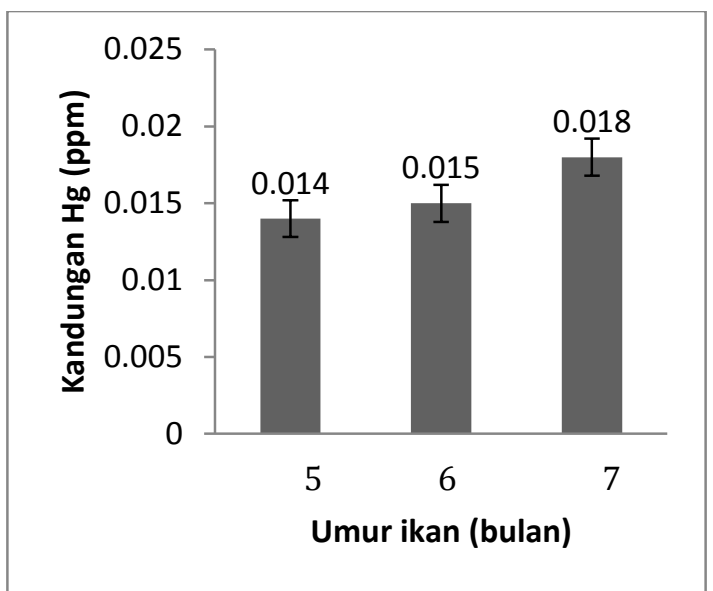

Gambar 2. Diagram kandungan merkuri rerata pada daging ikan nila umur 5-7 bulan pada keramba 2

Untuk mengetahui apakah terdapat perbedaan kandungan merkuri pada daging ikan nila pada keramba 3 berdasarkan umur ikan maka digunakan analisis varian (anova : single factor) dengan taraf nyata $(\alpha)$ sebesar $5 \%$. Berdasarkan data tersebut dapat diketahui bahwa $\mathrm{F}_{0}=4,290$ dan $\mathrm{F}_{\alpha}=$ 3,403 sehingga dapat disimpulkan bahwa nilai $\mathrm{F}_{0}$ lebih besar dari nilai $\mathrm{F}_{\alpha}\left(\mathrm{F}_{0}>\mathrm{F}_{\alpha}\right)$. Hal ini dapat menunjukkan bahwa $\mathrm{H}_{0}\left(\mu_{1}=\right.$ $\left.\mu_{2}=\mu_{3}\right)$ ditolak dan $\mathrm{H}_{1}\left(\mu_{1} \neq \mu_{2} \neq \mu_{3}\right)$ diterima. Artinya, kandungan merkuri pada daging ikan nila berumur 5 bulan tidak sama dengan kandungan merkuri pada daging ikan nila berumur 6 bulan dan tidak sama dengan kandungan merkuri pada daging ikan nila berumur 7 bulan. Dengan kata lain, terdapat perbedaan kandungan merkuri pada daging ikan nila keramba 3 antara umur 5, 6 dan 7 bulan.

Kandungan merkuri rerata pada daging ikan nila dari umur 5-6 bulan mengalami peningkatan. Untuk ikan nila umur 5 bulan adalah 0,014 ppm, 6 bulan adalah 0,015 ppm dan 7 bulan adalah 0,016 ppm. Hal ini disebabkan karena terjadinya akumulasi merkuri dalam tubuh ikan, dimana ikan dapat menyerap merkuri dengan efisien, tetapi ketika mengeluarkannya dari tubuh sangatlah lambat sehingga semakin panjang atau lama ikan nila terpapar merkuri maka kandungan merkuri dalam tubuh ikan tersebut akan semakin banyak.

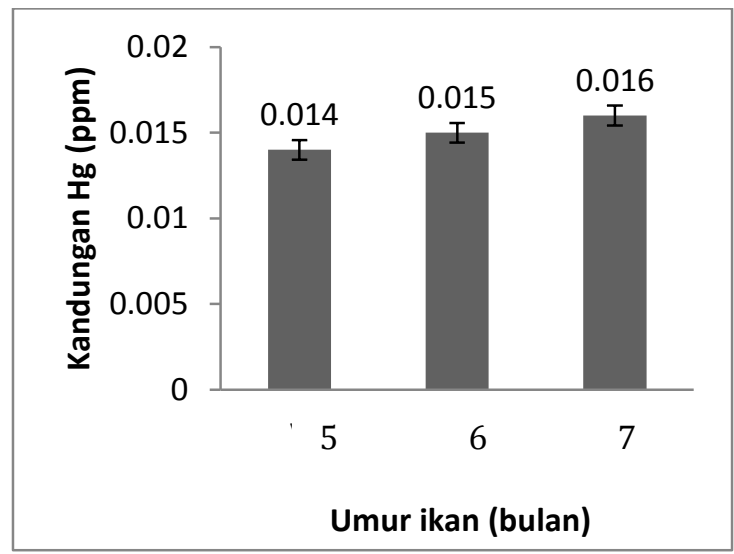

Gambar 3. Diagram kandungan merkuri rerata pada daging ikan nila umur 5-7 bulan pada keramba 3

Perbedaan Kandungan Merkuri Antara Daging Ikan Nila yang Diperoleh dari Keramba di Sungai Kahayan dengan
Daging Ikan Nila yang Diperoleh dari Kolam 
Kandungan merkuri pada daging ikan nila yang dipelihara di dalam kolam Jalan G. Obos XXV yang berumur 5 bulan dapat dilihat pada Tabel 2.

Untuk mengetahui apakah terdapat perbedaan antara kandungan merkuri antara daging ikan nila yang diperoleh dari kolam dengan daging ikan nila yang diperoleh dari keramba maka dilakukan analisis varian (anova : single factor) dengan taraf nyata 5\%. Data kandungan merkuri pada daging ikan nila yang berumur 5 bulan pada keramba 2 digunakan sebagai pembanding terhadap kandungan merkuri pada daging ikan nila yang diperoleh dari kolam.
Berdasarkan analisis varian dapat diketahui bahwa $\mathrm{F}_{0}=24,582$ dan $\mathrm{F}_{\alpha}=$ 4,494 sehingga dapat disimpulkan bahwa nilai $F_{0}$ lebih besar dari nilai $F_{\alpha}\left(F_{0}>F_{\alpha}\right)$. Hal ini dapat menunjukkan bahwa $\mathrm{H}_{0}\left(\mu_{1}=\right.$ $\left.\mu_{2}\right)$ ditolak dan $\mathrm{H}_{1}\left(\mu_{1} \neq \mu_{2} 3\right)$ diterima. Artinya, kandungan merkuri pada daging ikan nila berumur 5 bulan yang diperoleh dari kolam tidak sama dengan kandungan merkuri pada daging ikan nila berumur 5 bulan yang diperoleh dari keramba. Dengan kata lain, terdapat perbedaan kandungan merkuri pada daging ikan nila yang diperoleh dari kolam dengan kandungan merkuri pada daging ikan nila yang diperoleh dari keramba.

Tabel 2. Kandungan merkuri daging ikan nila yang diperoleh dari kolam

\begin{tabular}{ccc}
\hline Nama Sampel & Per ikan (ppm) & Rerata (ppm) \\
\hline Nila 5.1 & 0,012 & \\
Nila 5.2 & 0,012 & $0.0115 \pm 0,0005$ \\
Nila 5.3 & 0,011 & \\
\hline
\end{tabular}

Sumber : Data primer diolah

Kandungan merkuri rerata pada daging ikan nila yang diperoleh dari kolam sebesar $0.0115 \pm 0,0005 \mathrm{ppm}$ dan kandungan merkuri rerata pada daging ikan nila yang diperolah dari keramba sebesar $0,0145 \pm 0,0005 \mathrm{ppm}$. Hal ini dapat menunjukkan bahwa kandungan merkuri pada daging ikan nila di dalam kolam lebih rendah dibandingkan kandungan merkuri pada daging ikan nila di dalam keramba.
Kandungan merkuri pada daging ikan nila yang diperoleh dari kolam lebih sedikit karena peluang terpaparnya ikan nila tersebut dari air Sungai Kahayan yang telah tercemar merkuri sangat kacil. Hal ini disebabkan lokasi dari kolam tersebut jauh dari aliran sungai Kahayan. Diagram perbandingan kandungan merkuri antara daging ikan nila yang diperoleh dari kolam dan keramba dapat dilihat pada Gambar 4.

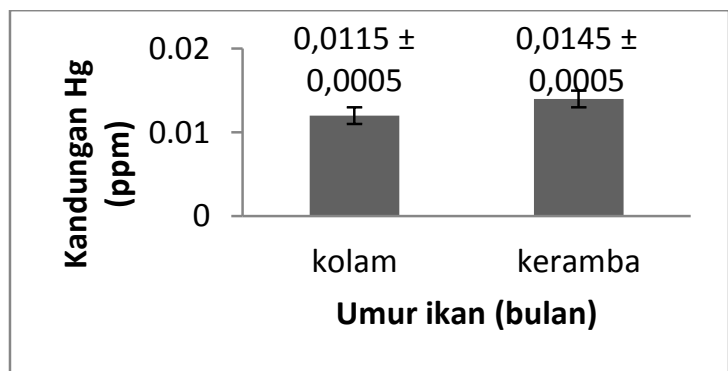

Gambar 4. Diagram kandungan merkuri rerata pada daging ikan nila umur 5-bulan yang dipelihara di dalam kolam dan keramba

Ikan nila yang dibudidayakan di dalam kolam mengandung merkuri diduga disebabkan karena air kolam yang merupakan media hidup ikan nila hidup telah mengandung merkuri yaitu 0,001 ppm. Selain itu, bibit ikan nila yang 
dibudidayakan di kolam diperoleh dari hasil budidaya keramba ikan nila di Sungai Kahayan yang telah terkontaminasi oleh merkuri.

\section{KESIMPULAN}

Adapun kesimpulan dari penelitian ini adalah :

1. Daging ikan nila yang diperoleh dari keramba di Sungai Kahayan umur 5-7 bulan mengandung merkuri sebesar $0,0145 \pm 0,0005$ ppm sampai $0,017 \pm$ 0,001 ppm dan kandungan merkuri tersebut lebih rendah dari batas maksimum cemaran merkuri dalam ikan dan hasil olahannya menurut SNI 7387 tahun 2009 yaitu adalah 0,5 ppm.

2. Dengan analisis varian (anova : single factor) dan taraf nyata $(\alpha)$ sebesar $5 \%$ maka dapat diketahui bahwa terdapat perbedaan kandungan merkuri pada daging ikan nila yang diperoleh dari keramba di Sungai Kahayan berdasarkan umur ikan, dimana kandungan merkuri pada daging ikan semakin meningkat seiring dengan bertambahnya umur ikan.

3. Dengan analisis varian (anova : single factor) dan taraf nyata $(\alpha)$ sebesar $5 \%$ maka dapat diketahui bahwa terdapat perbedaan kandungan merkuri antara daging ikan nila yang diperoleh dari Sungai Kahayan dengan daging ikan nila yang diperoleh dari kolam, dimana kandungan merkuri daging ikan nila yang diperoleh dari Sungai Kahayan lebih tinggi dari kandungan merkuri daging ikan nila yang diperoleh dari kolam. Kandungan merkuri daging ikan nila yang diperoleh dari kolam adalah sebesar $0,0115 \pm 0,0005 \mathrm{ppm}$.

\section{SARAN}

Saran dalam penelitian ini adalah :
1. Untuk penelitian lebih lanjut dapat mempertimbangkan analisis kandungan merkuri berdasarkan lokasi dan jenis ikan, tingkat kedalaman air serta pengaruh merkuri secara morfologis dan fisiologis ikan.

2. Perlu adanya upaya budidaya nila yang bebas merkuri dengan memperhatikan tempat budidaya, asal bibit nila dan pakan yang diberikan agar dihasilkan ikan nila konsumsi yang bebas merkuri.

3. Limbah merkuri dari kegiatan yang menggunakan merkuri jangan langsung dibuang ke lingkungan tetapi sebaiknya dikomplekskan dengan metil sehingga merkuri dapat dipergunakan kembali dan tidak mencemari lingkungan.

4. Perlu adanya pengawasan dan pengendalian yang lebih ketat dari pihak-pihak terkait tentang penggunaan merkuri.

\section{DAFTAR PUSTAKA}

Badan Pusat Statistik Provinsi Kalimatan Tengah. 2013. Katalog BPS No: 1101002.62: Statistik Daerah Provinsi Kalimantan Tengah 2013. Palangka Raya.

Badan Standardisasi Nasional. 2009. SNI 7387 : Batas Cemaran Maksimum Logam Berat Dalam Pangan. Jakarta.

Dinas Kelautan dan Perikanan Provinsi Kalimatan Tengah. 2011. Berita PHP.

(http://www.djpb.kkp.go.id/Berita php. html.) (Diakses tanggal 12 Desember 2013).

Jewett dan Duffy. 2007. Mercury In Fishes of Alaska, With Emphasis On Subsistence Species. Science of The Total Environment 387 : 3-27. 